\title{
PERBEDAAN TINGKAT KECEMASAN IBU PRA MENOPAUSE SEBELUM DAN SESUDAH DIBERI KONSELING INFORMASI EDUKASI (KIE) TENTANG MENOPAUSE
}

\author{
${ }^{1}$ Dwi Suprapti \\ ${ }^{1}$ STIKes Borneo Cendekia Medika Pangkalan Bun \\ ${ }^{1}$ Email : dwi.suprapti99@gmail.com
}

\begin{abstract}
ABSTRAK
Menopause merupakan hal yang fisiologis dialami oleh setiap wanita yang ditandai dengan berhentinya masa subur. Masa ini akan mengalami keluhan baik fisik maupun psikologis yang berpengaruh terhadap kecemasan seseorang. Kecemasan adalah respon individu terhadap suatu keadaan yang tidak menyenangkan dan dialami oleh semua orang. Kecemasan tersebut dapat teratasi jika ibu mempunyai pengetahuan yang cukup tentang menopause, sehingga ibu perlu mengikuti kegiatan pendidikan kesehatan tentang menopause. Tujuan penelitian ini untuk mengetahui perbedaan tingkat kecemasan ibu pra menopause sebelum dan sesudah diberi KIE tentang menopause. Metode penelitian ini menggunakan preeksperimental design dengan teknik one group pre-test post-test, populasi penelitian sebanyak 201 orang dan sampel sebanyak 20 ibu pra menopause usia 4150 tahun dengan pengambilan sampel menggunakan simple random sampling dan data analisis menggunakan uji paried $T$ - test.Hasil penelitian menunjukkan bahwa ada perbedaan yang signifikan pemberian KIE tentang menopause terhadap tingkat kecemasan ibu pra menopause pada pre-test tingkat kecemasan ringan sebanyak $40,0 \%$, cemas sedang 55,0\%, dan cemas berat 5,0\% dan mengalami penurunan pada saat post-test dengan tingkat kecemasan ringan $60,0 \%$, sedang 35,0\%, dan berat tidak ada kecemasan $0 \%$ dengan $\mathrm{p}$-value $=0,000(\mathrm{p}<0,05)$. Dan pada hasil penelitian menunjukkan bahwa sebelum diberikan KIE tentang menopause rata-rata skor kecemasan ibu sebesar 16,40, kemudian berkurang menjadi 13,15 setelah diberikan KIE tentang menopause. Saran bagi masyarakat terutama wanita pra menopause diharapkan dapat meningkatkan pengetahuan tentang menopause sehingga dapat menurunkan tingkat kecemasan dan lebih siap lagi dalam menghadapi menopause.
\end{abstract}

Kata kunci : Kecemasan, Ibu Pra Menopause, KIE (Komunikasi Informasi Edukasi)

DIFFERENCES IN PREVENTION OF MENOPAUSE PREVENTION MOTHER BEFORE AND AFTER THE EDUCATION INFORMATION (CIE) CONCELING ABOUT MENOPAUSE 


\begin{abstract}
Menopause is a physiological thing experienced by every woman which is marked by the cessation of fertility. This period will experience both physical and psychological complaints that affect a person's anxiety. Anxiety is an individual response to an unpleasant situation experienced by everyone. This anxiety can be overcome if the mother has enough knowledge about menopause, so the mother needs to participate in health education activities about menopause. The purpose of this study was to determine differences in pre-menopausal maternal anxiety levels before and after IEC given about menopause. This research method uses preexperimental design with one group pre-test post-test technique, the study population is 201 people and a sample of 20 pre-menopausal mothers aged 41-50 years by sampling using simple random sampling and data analysis using paried $T$ test - test. The results of the study showed that there were significant differences in the provision of IEC about menopause against pre-menopausal maternal anxiety levels in pre-test mild anxiety levels of $40.0 \%$, moderate anxiety $55.0 \%$, severe anxiety $5.0 \%$ and experienced decreased at the time of the post-test with a mild anxiety level of $60.0 \%$, moderate $35.0 \%$, and severe $0 \%$ anxiety with no $p$-value = 0,000 ( $p$ <0.05). And the results of the study showed that before IEC was given about menopause the average maternal anxiety score was 16.40, then reduced to 13.15 after IEC was given about menopause. Suggestions for the public, especially pre-menopausal women are expected to increase knowledge about menopause so that it can reduce anxiety levels and be better prepared in the face of menopause.
\end{abstract}

Keywords: Anxiety, Pre-Menopausal Mothers, IEC (Information Communication Education)

\section{PENDAHULUAN}

Sindroma menopause dialami oleh banyak wanita hampir di seluruh dunia, sekitar 70-80\% wanita Eropa, 60\% di Amerika, 57\% di Malaysia, $18 \%$ di Cina dan 10\% di Jepang dan Indonesia . Berdasarkan data Badan Pusat Statistik (BPS) dengan proyeksi penduduk tahun 2008, terdapat 5.320.000 perempuan Indonesia memasuki masa menopause per tahunnya, sementara sekitar 25 juta perempuan di seluruh dunia diperkirakan mengalami menopause. Data Departemen Kesehatan tahun 2006 di Indonesia jumlah wanita yang telah mengalami menopause telah mencapai 30 juta jiwa dan yang mengalami kecemasan sebanyak 10\%. Di Jawa Timur tahun 2006 wanita yang telah mengalami menopause sebanyak 5 juta jiwa dan yang mengalami kecemasan sebanyak $18 \%$.

Di Indonesia sebagian besar wanita tidak mengetahui dampak yang akan 
timbul dalam memasuki masa menopause, dimana ketidaktahuan itu didasari pada pandangan yang menganggap bahwa menopause merupakan suatu gejala yang alami. Padahal saat memasuki masa tidak haid atau menopause, seorang wanita bisa saja menjadi rentan terhadap penyakit fisik seperti gelisah, sakit kepala, sakit sendi dan otot, sakit punggung yang disebabkan oleh berkurangnya produksi kalsium didalam tubuh, pengeroposan tulang, dan penyakit jantung. Menopause juga berdampak pada segi psikologi, seperti pudarnya daya pikat fisik dan seksual, bahkan pikiran yang menganggap bahwa usia lanjut adalah anggota masyarakat yang tidak produktif dan hanya menciptakan beban dalam hidup. Hal ini menyebabkan wanita merasa murung, merasa tidak disayang, mudah tersinggung, mudah marah dan cemas. Kecemasan adalah respon individu terhadap suatu keadaan yang tidak menyenangkan dan dialami oleh semua orang (Mangoenprasodjo,2004).

Kecemasan / ansietas adalah kekhawatiran yang tidak jelas dan menyebar, yang berkaitan dengan perasaan tidak pasti dan tidakberdaya. Kecemasan adalah respon emosional terhadap penilaian yang menggambarkan keadaan khawatir, gelisah, takut tidak tentram disertai berbagai keluhan fisik. Keadaan tersebut dapat terjadi dalam berbagai situasi kehidupan maupun gangguan sakit. Selain itu kecemasan dapat menimbulkan reaksi tubuh yang akan terjadi secara berulang, seperti rasa kosong di perut, sesak nafas, jantung berdebar, keringat banyak, sakit kepala , rasa keinginan buang air kecil dan buang air besar, perasaan ini disertai perasaan ingin bergerak untuk lari menghindar hal yang dicemaskan (Stuart, 2007).

Kecemasan terjadi sebagai akibat dari ancaman terhadap harga diri atau identitas diri yang sangat mendasar bagi individu. Kecemasan tersebut dapat teratasi jika ibu mempunyai pengetahuan tentang menopause, sehingga ibu perlu mengikuti kegiatan pendidikan kesehatan tentang menopause karena dengan kegiatan tersebut dapat menambah informasi tentang menopause dan ibu lebih siap dalam menghadapi masa menopause (Suliswati,dkk, 2005).

Pengetahuan tersebut salah satunya didapat dari Komunikasi Informasi Edukasi (KIE). Menurut Taufik (2010), KIE merupakan suatu strategi dari metode pendidikan kesehatan dengan meningkatkan hubungan saling percaya dengan klien sehingga dapat membantu perubahan perilaku kearah yang positif. Pentingnya KIE mengenai menopause sangatlah diperlukan untuk ibu-ibu pra menopause, karena banyak ibu yang merasa cemas mencapai masa menopause nya, dan sudah saatnya wanita mengetahui tentang menopause agar kecemasan yang sering terjadi terhadap wanita pra menopause dapat terkurangi dengan adanya pemberian KIE tentang menopause. Kecemasan saat menopause dapat dikurangi dengan peningkatan pengetahuan ibu saat menjelang menopause. 


\section{METODE PENELITIAN}

Jenis penelitian ini adalah Pre Eksperimental Design. Pendekatan yang dilakukan dalam penelitian ini adalah dengan teknik one group pre test and post test yaitu suatu penelitian yang dilakukan untuk menilai satu kelompok saja secara utuh tanpa menggunakan kelompok pembanding atau kontrol. Metode ini memberikan perlakuan kepada responden dengan memberikan pretest terlebih dahulu kemudian dilakukan intervensi setelah itu diberi posttest.

Variabel independen dalam penelitian ini adalah tingkat kecemasan ibu pra menopause dan variabel dependen dalam penelitian ini adalah pemberian konseling, informasi dan edukasi (KIE) tentang menopause.

Analisis Univariat dalam penelitian ini dilakukan untuk mengetahui distribusi frekuensi tingkat kecemasan ibu pra menopause sebelum dan sesudah diberi KIE tentang menopause. Analisis yang digunakan untuk mengetahui perbedaan tingkat kecemasan ibu pra menopause sebelum dan sesudah diberi KIE tentang menopause. Maka uji normalitas data yang digunakan adalah uji Shapiro- wilk karena sampel kurang dari 50 (sampel kecil).

\section{HASIL PENELITIAN}

Variabel independen dalam penelitian ini adalah tingkat kecemasan ibu pra menopause dan variabel dependen dalam penelitian ini adalah pemberian konseling, informasi dan edukasi
(KIE) tentang menopause. Jumlah responden sebanyak 20 ibu pra menopause yang berumur 41-50 tahun, pengukuran dilakukan sebanyak dua kali, yaitu pengukuran tingkat kecemasan sebelum dan sesudah di beri KIE tentang menopause.

1. Tingkat Kecemasan Ibu Pra Menopause sebelum diberi KIE tentang menopause

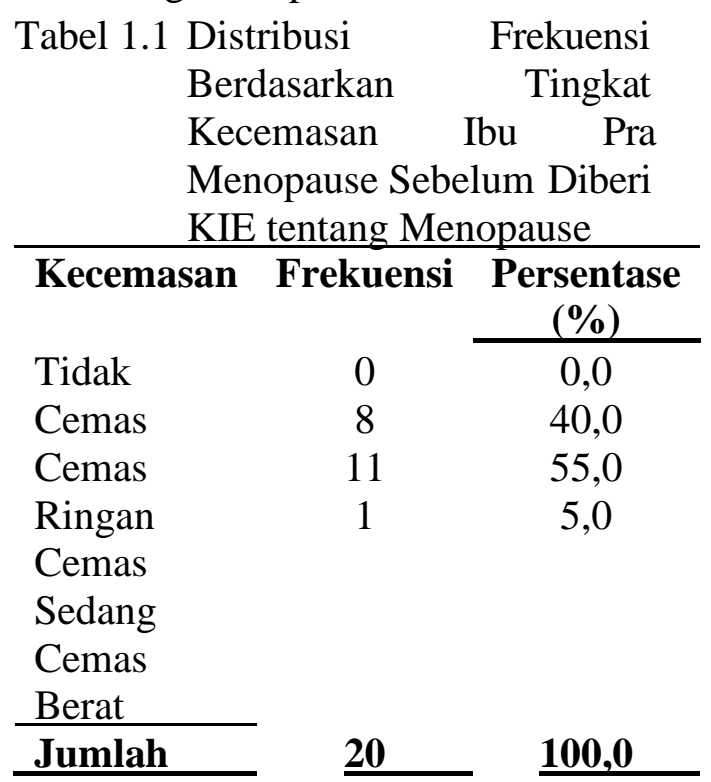

Berdasarkan tabel 4.1, dapat diketahui bahwa tingkat kecemasan ibu pra menopause sebelum diberi KIE tentang menopause sebagian besar mengalami cemas sedang, yaitu sejumlah 11 orang $(55,0 \%)$.

2. Kecemasan Ibu Pra Menopause Sesudah diberikan KIE

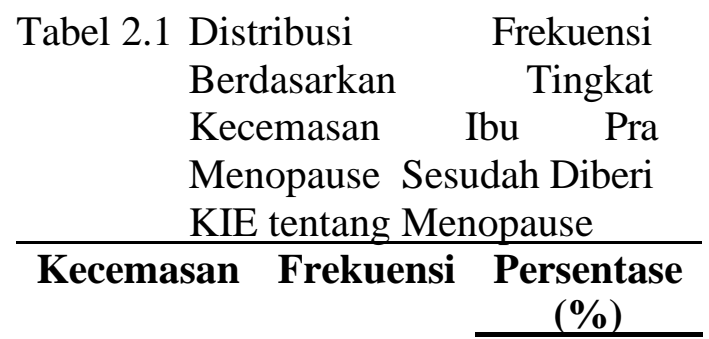




\begin{tabular}{|c|c|c|}
\hline Tidak & 1 & 5,0 \\
\hline Cemas & 12 & 60,0 \\
\hline Cemas & 7 & 35,0 \\
\hline Ringan & 0 & 0,0 \\
\hline Cemas & & \\
\hline Sedang & & \\
\hline Cemas & & \\
\hline Berat & & \\
\hline Jumlah & 20 & 100,0 \\
\hline
\end{tabular}

Berdasarkan tabel 4.2, dapat diketahui bahwa tingkat kecemasan ibu pra menopause sesudah diberi KIE tentang menopause sebagian besar mengalami cemas ringan yaitu sejumlah 12 orang $(60,0 \%)$.

3. Perbedaan Tingkat Kecemasan Ibu Pra Menopause Sebelum dan Sesudah diberi KIE tentang Menopause

Tabel 3.1 Perbedaan Tingkat Kecemasan Ibu Pra Menopause Sebelum dan Sesudah Diberi KIE tentang Menopause di Desa Sidomukti Kecamatan Bandungan Kabupaten Semarang

\begin{tabular}{|c|c|c|c|c|c|}
\hline $\begin{array}{l}\text { Variab } \\
\text { el }\end{array}$ & $\begin{array}{l}\text { Perlak } \\
\text { uan }\end{array}$ & $\mathbf{n}$ & $\begin{array}{c}\text { Me } \\
\text { an }\end{array}$ & SD & $\begin{array}{l}\text { p- } \\
\text { val } \\
\text { ue } \\
\end{array}$ \\
\hline \multirow{4}{*}{$\begin{array}{l}\text { Tingkat } \\
\text { Kecem } \\
\text { asan }\end{array}$} & Sebelu & 2 & 16 & 5,5 & 0,0 \\
\hline & $\mathrm{m}$ & 0 & 40 & 10 & 00 \\
\hline & Sesuda & 2 & 13, & 5,5 & \\
\hline & $\mathrm{h}$ & 0 & 15 & 85 & \\
\hline
\end{tabular}

Berdasarkan tabel tabel 4.3 menunjukkan bahwa sebelum diberikan KIE tentang menopause rata-rata skor kecemasan ibu sebesar 16,40 , kemudian berkurang menjadi 13,15 setelah diberikan KIE tentang menopause.
Berdasarkan uji $\mathrm{t}$ diperoleh nilai $\mathrm{t}$ hitung 5,695 dengan p-value 0,000. Oleh karena p-value $0,000<\alpha(0,05)$ maka Ho ditolak. Hal ini menunjukkan bahwa ada perbedaan yang signifikan tingkat kecemasan ibu pra menopause sebelum dan sesudah diberi KIE tentang menopause.

\section{PEMBAHASAN}

1. Tingkat Kecemasan Ibu Pra Menopause Sebelum diberi KIE tentang Menopause

Berdasarkan hasil penelitian menunjukkan bahwa tingkat kecemasan ibu pra menopause sebelum diberi KIE tentang menopause dengan kategori cemas ringan sejumlah 8 orang $(40 \%)$, dengan kategori cemas sedang sejumlah 11 orang (55\%), dan dengan kategori cemas berat 1 orang (5\%). Ini menunjukkan bahwa sebagian besar tingkat kecemasan ibu pra menopause sebelum diberi KIE tentang menopause dengan kategori sedang.

Kecemasan ibu pra menopause dengan kategori sedang ini memang biasa terjadi sebab hal ini berhubungan dengan faktor yang mempengaruhi kecemasan, seperti faktor lingkungan, faktor emosi yang ditekan, faktor sebab-sebab fisik, dan juga faktor keturunan. Hal ini didukung, ketidakteraturan haid yang terjadi, secara bawah sadar meningkatkan kecemasan wanita bahwa daya tarik seksual dan fisiknya berkurang. Dia menjadi tua, merasa ditolak, dan mencapai akhir dari kehidupannya (Yatim, 2002). 
Rentang umur responden pada penelitian ini yang mengalami masa pra menopause yaitu 41-50 tahun. Masa pra menopause merupakan suatu fase alamiah yang akan dialami oleh setiap wanita yang biasanya terjadi diatas usia 40 tahun. Responden berada pada fase klimakterium, dimana pada umur ini keluhankeluhan yang dirasakan akibat dari perubahan fisik dan psikologis mencapai puncaknya. Hal ini sesuai dengan pendapat Rambulangi (2006), yang menyatakan bahwa umur seorang perempuan memasuki usia pertengahan empat puluhan, fungsi ovarium akan mulai menurun. Sehingga menyebabkan kadar hormon dalam tubuh tidak seimbang, yang akhirnya menyebabkan berbagai gangguan.

Wanita menjelang menopause akan mengalami penurunan berbagai fungsi tubuh, sehingga akan berdampak pada ketidaknyamanan dalam menjalani kehidupannya. Untuk itu, penting bagi seorangwanita selalu berfikir positif bahwa kondisi tersebut merupakan sesuatu yang sifatnya alami, seperti halnya keluhan yang muncul padafase kehidupannya yang lain. Tentunya sikap yang positif ini bisa muncul jika diimbangi oleh informasi atau pengetahuan yang cukup, sehinggaibu lebih siap baik secara fisik, mental, dan spiritual (Kasdu, 2002).

2. Tingkat Kecemasan Ibu Pra Menopause Sesudah diberi KIE tentang Menopause

Berdasarkan hasil penelitian menunjukkan bahwa tingkat kecemasan ibu pra menopause sesudah diberi KIE tentang menopause sebagian besar dalam kategori ringan sejumlah 12 orang $(60 \%)$, dan kategori sedang sejumlah 7 orang (35\%). Ini menunjukkan bahwa tingkat kecemasan ibu pra menopause sesudah diberi KIE tentang menopause dalam kategori ringan.

Berdasarkan hasil tersebut, sebagian besar kecemasan ini berubah dari sedang menjadi ringan. Perubahan ini bisa terjadi karena pengetahuan ibu tentang menopause meningkat dari tidak tahu menjadi tahu. Ibu yang semula tidak tahu tentang menopause sudah tentu merasa khawatir tentang perubahan-perubahan yang terjadi baik pada seksual maupun fisiknya. Namun dengan pengetahuan tentang menopause, ibu menjadi tidak khawatir lagi, karena hal ini memang wajar terjadi pada setiap wanita dalam masa hidupnya.

Menurut Hawari (2006), kecemasan adalah ketegangan, rasa yang tidak aman yang lahir dari diri sendiri karena ada sesuatu yang tidak menyenangkan tetapi sumbernya sebagian besar tidak diketahui dan berasal dari dalam. Kecemasan adalah gejala yang tidak spesifik yang sering ditemukan dan sering kali suatu emosi yang normal. Kecemasan dapat timbul karena orang berusaha membuat sebuah keputusan sebelum memiliki pengetahuan yang cukup untuk dijadikan dasar keputusan mereka. Meskipun pengetahuan seseorang sudah baik namun tingkat kecemasan seseorang bisa saja meningkat yang dapat disebabkan perasaan takut, gelisah yang kemudian menimbulkan 
rasa cemas yang diakibatkan oleh wanita pra menopause tidak siap menghadapi menopause.

Menurut pendekatan kognitif, dalam ilmu psikologi pada dasarnya gangguan emosi (takut, cemas, stres) yang dialami manusia, sangat ditentukan oleh bagaimana individu menilai, menginterpretasikan atau mempersiapkan peristiwa yang dialaminya. Jadi bagaimana individu mempersiapkan atau menilai menopause akan berpengaruh pada kondisi emosi psikologinya. Bila wanita memandang menopause sebagai hal yang mengerikan maka iapun akan menghadapi menopause dengan penuh kecemasan, ketakutan stres bahkan depresi (Hawari, 2006). Kecemasan menghadapi menopause adalah perasaan gelisah, khawatir dari adanya perubahan-perubahan fisik, sosial maupun seksual sepengaruh dengan menopause. Faktor penyebab kecemasan menghadapi menopause, sebuah permasalahan yang muncul pasti ada yang melatarbelakangi nya, sehingga permasalahan itu timbul demikian juga kecemasan yang dialami seseorang, ada penyebab yang melatarbelakangi nya. Menurut Hawari (2006), kecemasan disebabkan oleh dorongan-dorongan seksual yang tidak mendapatkan kepuasan dan terhambat, sehingga menyebabkan banyak konflik batin. Stressor pencetus kecemasan dapat dikelompokkan ada dua yaitu: ancaman terhadap integritas fisik, meliputi ketidak mampuan fisiologis yang akan datang atau menurutnya kapasitas untuk melakukan aktivitas hidup sehari - hari, dan ancaman terhadap sistem diri, dapat membahayakan identitas, harga diri, dan fungsi integritas sosial. Faktor internal dan eksternal dapat mengancam harga diri. Faktor eksternal meliputi kehilangan nilai dari akibat kematian, perceraian atau bahkan perubahan jabatan. Faktor internal meliputi kesulitan interpersonal dirumah atau tempat kerja.

Menopause sebagai sebagian dari proses kehidupan yang memang tidak dapat dihindari oleh setiap wanita dalam menghadapi masa menua nya, maka menurun nya fungsi organ bahkan berhentinya produksi hormon estrogen harus dihadapi dengan penuh tawakkal, keikhlasan dan sikap positif itu merupakan suatu hal wajar. Maka sangat perlu wanita yang mengalami menopause mencari informasi yang obyektif mengenai segala sesuatu yang menyangkut menopause. Khususnya bagi wanita yang belum mengalami menopause hal ini sangat penting yang tidak kalah penting nya adalah membina komunikasi dengan suami dan anak-anak, agar semuanya mengerti dan dapat memahami kondisi istri dan ibunya. Dukungan dari seluruh anggota keluarga besar artinya bagi kondisi kesehatan mental wanita yang mengalami menopause dan yang paling penting peningkatan kehidupan agama, sehingga dapat lebih menerima ketentuan Tuhan dengan penuh tawakkal dan ikhlas (Hammasa, 2004).

3. Perbedaan Tingkat Kecemasan Ibu Pra Menopause Sebelum dan 
Sesudah diberi KIE tentang Menopause

Berdasarkan hasil penelitian menunjukkan bahwa rata-rata skor tingkat kecemasan ibu sebelum diberi KIE tentang menopause sebesar 16,40, kemudian skor kecemasan berkurang menjadi 13,15 sesudah diberi KIE tentang menopause.

Hal ini memang sesuai dengan tujuan KIE, yang merupakan suatu strategi dari metode pendidikan kesehatan dengan meningkatkan hubungan saling percaya dengan klien sehingga dapat membantu perubahan perilaku ke arah yang positif. KIE dalam program kesehatan ditujukan untuk meningkatkan kepedulian dan mengubah sikap untuk menghasilkan suatu perubahan perilaku yang spesifik, dengan perubahan perilaku ini akhirnya dapat menurunkan tingkat kecemasan terhadap masalah yang dialami peserta KIE (Taufik,2010). Selain itu, KIE juga untuk meningkatkan pengetahuan, sikap, meletakkan dasar bagi mekanisme sosio-kultural yang dapat menjamin keberlangsungannya proses penerimaan (Hartanto, 2004).

Berdasarkan uji t dependen didapatkan nilai t hitung sebesar 5,965 dengan $p$ value 0,000 . Oleh karena $p$-value $<\alpha$ $(0,05)$, maka Ho ditolak. Hal ini menunjukkan bahwa ada perbedaan yang signifikan tingkat kecemasan ibu pra menopause sebelum dan sesudah diberi KIE tentang menopause.

Menurut Taufik (2010) bahwa KIE merupakan proses pemberian informasi obyektif dan lengkap, dilakukan secara sistematik dengan panduan keterampilan komunikasi interpersonal, teknik bimbingan dan penguasaan pengetahuan klinik. KIE membantu seseorang mengenali kondisinya saat ini, masalah yang sedang dihadapi dan menentukan jalan keluar atau upaya untuk mengatasi masalah tersebut. Oleh karena itu, dengan KIE tentang menopause, ibu dapat terbantu dalam menghadapi masalahnya, sehingga tidak khawatir lagi akan perubahan kondisi seksual dan fisiknya.

Taufik (2010) menambahkan bahwa, KIE merupakan suatu strategi dari metode pendidikan kesehatan dengan meningkatkan hubungan saling percaya dengan klien sehingga dapat membantu perubahan perilaku ke arah yang positif. Komunikasi Informasi Edukasi mengenai menopause sangatlah diperlukan oleh wanita karena banyak wanita merasa cemas mencapai masa menopause, sudah saatnya wanita mengetahui tentang menopause. Kecemasan saat menopause dapat dikurangi dengan peningkatan pengetahuan ibu saat menjelang menopause.

Ibu dengan pengetahuan yang baik tentang menopause tentunya tidak akan khawatir terhadap masalahmasalah yang dihadapi menjelang menopause, karena ibu dapat melakukan tindakan-tindakan yang benar dalam mengahadapi menopause. Hal ini sesuai dengan hasil penelitian yang dilakukan oleh Dewi, S. (2008) dengan judul Hubungan Tingkat Pengetahuan Tentang Menopause Terhadap Tingkat Kecemasan Pada Ibu Pra Menopause Di Dusun Mading 


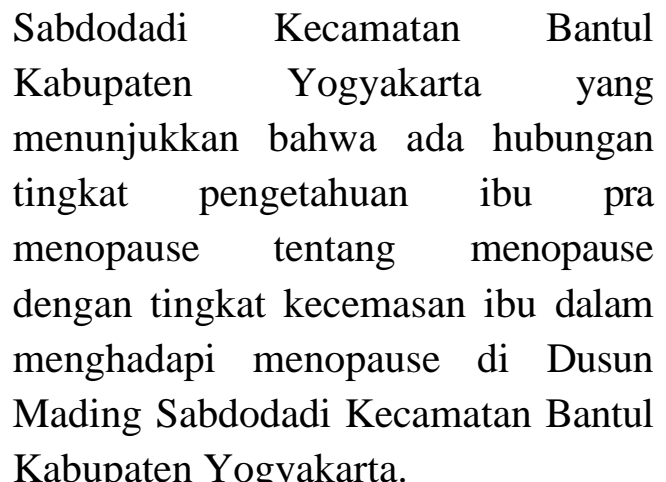
Adanya pendidikan kesehatan melalui KIE tentang menopause, ditujukan guna membantu ibu mengenalikondisi menopause nya saat ini, masalah yang sedang dihadapi dan menentukan jalan keluar atau upaya untuk mengatasi masalah tersebut. Hal ini tentunya dapat meringankan beban dan kekhawatiran ibu dalam mengahadapi menopause nya, karena memang dalam menghadapi masa menopause, dibutuhkan dukungan sosial bagi wanita untuk membantu dalam menghadapi masalah yang terjadi pada masa menopause. Selain itu, peran suami juga sangat diperlukan, kesabaran, bimbingan, dan semangat dari suami akan juga sangat diperlukan, kesabaran, bimbingan, dan semangat dari suami sangat membantu wanita menghadapi masa ini. Liewellyn Jones (2005) mengemukakan bahwa, jika seorang wanita mempunyai konflik dalam kehidupan kebanyakan mereka mencari bantuan dengan orang terdekat bahkan sampai berkonsultasi dengan ahli profesional untuk mencari pemecahan masalah yang dihadapinya dan keadaan ini dipermudah lagi dengan adanya dukungan suami dan keluarga.

\section{KESIMPULAN DAN SARAN Kesimpulan}

Ada perbedaan yang signifikan tingkat kecemasan ibu pra menopause sebelum dan sesudah diberi KIE tentang menopause, dengan $p$-value $0,000<\alpha(0,05)$.

\section{Saran}

Hasil penelitian ini khususnya bagi bidan diharapkan dapat lebih aktif lagi dalam memberikan pemahaman tentang menopause bagi ibu pra menopaus. Hal ini bisa dilakukan melalui berbagai penyediaan informasi, misalnya penyuluhan atau memberikan informasi secara langsung pada saat ibu mengunjungi fasilitas kesehatan.

Sebagai sumber referensi, sumber bacaan dan sebagai dasar untuk program bimbingan tentang menopause.

Dapat meningkatkan pengetahuan wanita pramenopause tentang menopause sehingga dapat menurunkan tingkat kecemasan dalam menghadapi menopause.

Memperoleh informasi ilmiah tentang KIE khususnya menopause dan dapat mengaplikasikan teori yang didapat tentang metode peneliti.

\section{DAFTAR PUSTAKA}

Dewi, S.(2008). Hubungan tingkat pengetahuan tentang menopause terhadap tingkat kecemasan pada ibu premenopause di dusun mading sabdodadi bantul yogyakarta. Akademi Kebidanan Yogyakarta. 
Hammasa, S.N. 2004. Menopause. Kiat wanita lansia sehat menuju khusnul khatimah. Solo: Ma'sum Press.

Hartanto.(2004). Kontrasepsi. Yogyakarta: Pustaka Sinar Harapan.

Hawari,D.(2004). Manajemen stres, cemas, dan depresi. Jakarta: Fakultas Kedokteran Universitas Indonesia.

Hawari, D. (2006). Menopause. Diakses pada 15 November 2013. Sumber dari http://klinis.wordpress.com.

Kasdu, D. (2002). Kiat sehat dan bahagia di usia menopause. Jakarta: Puspa Swara.

Mangoenprasodjo,S.A.(2004). Siapa takut menopause: kiat memasuki waktu paruh baya tanpa rasa was-was dan cemas. Yogyakarta: Think Fresh.

Rambulangi, J. (2006). Tantangan, harapan, dan pengobatan alternatif dalam meningkatkan produktivitas dan kualitas hidup wanita menopause, majalah obstetri \& ginekologi. Jakarta: Yayasan BinaPustaka.

Stuart, G. (2007). Buku saku keperawatan jiwa. Jakarta: EGC.

Suliswati,dkk. (2005). Konsep dasar keperawatan kesehatan jiwa. Jakarta: Prekindo

Taufik, M. (2010). Komunikasi terapeutik dan konseling dalam praktek kebidanan. Jakarta: PT. Salemba Medika.
Yatim, F. (2002). Haid tidak wajar dan menopause. Jakarta: Pustaka Populer Obor. 